\title{
Hubungan Kadar Hemoglobin dengan Kejang Demam pada Anak yang Disebabkan Infeksi Saluran Pernapasan Akut: Studi Kasus Kontrol
}

\author{
Amalia Aswin, ${ }^{*}$ Annisa Muhyi, ${ }^{* *}$ Nurul Hasanah ${ }^{* * *}$ \\ *Program Studi Kedokteran, ${ }^{* *}$ Laboratorium Ilmu Kesehatan Anak, ${ }^{* *}$ Laboratorium Histologi Fakultas Kedokteran Universitas \\ Mulawarman, Samarinda
}

Latar belakang. Kejang demam adalah bangkitan kejang yang terjadi pada anak berusia 6 bulan sampai 5 tahun tanpa disebabkan
oleh proses intrakranial. Kejang demam merupakan kelainan neurologi tersering yang dijumpai pada anak.
Tujuan. Untuk mengetahui hubungan kadar hemoglobin dengan kejang demam pada anak yang disebabkan ISPA.
Metode. Penelitian analitik observasional dengan desain kasus kontrol. Data diambil dari rekam medik di RSUD Abdul Wahab Sjahranie
Samarinda tahun 2016-2017 menggunakan teknik purposive sampling. Variabel bebas adalah kadar hemoglobin, sedangkan variabel
tergantung adalah kejang demam yang disebabkan ISPA. Analisis statistik menggunakan uji t tidak berpasangan dan chi-square $\left(x^{2}\right)$,
kemaknaan ditentukan berdasarkan nilai p $<0,05$.
Hasil. Didapatkan sebanyak 62 pasien dengan rincian 31 kejang demam dan 31 demam tanpa kejang. Prevalensi kejang demam pada
anak laki-laki $71 \%$, sedangkan perempuan $29 \%$. Angka kejadian terbanyak kejang demam adalah usia $0-12$ bulan dan gizi baik.
Berdasarkan analisis data menggunakan uji t tidak berpasangan didapatkan rata-rata kadar hemoglobin pada kejang demam adalah
11,04 g/dL dan demam tanpa kejang $11,6 \mathrm{~g} / \mathrm{dL}\left(\mathrm{p}=0,023\right.$ ). Pada uji chi-square $\left(x^{2}\right)$, menunjukkan terdapat hubungan yang bermakna
antara kadar hemoglobin dengan kejang demam yang disebabkan ISPA ( $\mathrm{p}=0,032$, OR=3,906) Kesimpulan. Terdapat hubungan kadar hemoglobin dengan kejang demam pada anak yang disebabkan ISPA. Sari Pediatri 2019;20(5):270-5

Kata kunci: kejang demam, kadar hemoglobin, ISPA

\section{Relationship Between Hemoglobin Count and Febrile Seizure Cause by Respiratory Tract Infection: A Case-Control Study}

Amalia Aswin, ${ }^{*}$ Annisa Muhyi, ${ }^{* *}$ Nurul Hasanah ${ }^{* * *}$

Background. The febrile seizure is a convulsion disorder in children aged 6 months to 5 years without any intracranial disorder. The febrile seizure is the most common neurological disorder found in children.

Objective. To determine the relationship between hemoglobin count and febrile seizure in children caused by respiratory tract infection. Methods. This research was observational analytic with case-control design. Data were obtained from medical records of patients at RSUD Abdul Wahab Sjahranie Samarinda from 2016-2017 using purposive sampling technique. The independent variable was hemoglobin count, while the dependent variable was febrile seizure caused by respiratory tract infection. Data were analyzed using independent t-test and chi-square test, with p-value $<0.05$ was considered statistically significant.

Result. The subject was 62 patients that divided into two groups, 31 febrile seizure and 31 febrile without convulsion. Febrile seizure prevalence in male was $71 \%$ and female was $29 \%$. Febrile seizure was more frequent in children aged 0-12 months and good nutritional status. The result of independent $\mathrm{t}$-test analysis showed that the median of hemoglobin count in febrile seizure was 11.04 $\mathrm{g} / \mathrm{dL}$ and febrile without convulsion was $11.6 \mathrm{~g} / \mathrm{dL}(\mathrm{p}=0.023)$. Data analysis with chi-square test showed there is a relationship between hemoglobin count and febrile seizure caused by respiratory tract infection $(\mathrm{p}=0.032, \mathrm{OR}=3.906)$

Conclusion. There is a relationship between hemoglobin count and febrile seizure in children caused by respiratory tract infection. Sari Pediatri 2019;20(5):270-5

Keywords: febrile seizure, hemoglobin count, respiratory tract infection

Alamat korespondensi: Amalia Aswin. Program Studi Kedokteran Fakultas Kedokteran Universitas Mulawarman. Jl. Krayan, Kampus Gn. Kelua, Samarinda 75123. Email: x11amaliaaswin@gmail.com 
$\mathrm{K}$

ejang demam merupakan kelainan neurologi tersering yang dijumpai pada anak. Kejang demam ialah bangkitan kejang yang tahun yang mengalami kenaikan suhu tubuh di atas $38^{\circ} \mathrm{C}$ dengan metode pengukuran suhu apa pun yang tidak disebabkan oleh proses intrakranial. ${ }^{1}$

Insiden kejang demam di Asia meningkat dua kali lipat bila dibanding di Eropa dan Amerika Serikat, di Jepang berkisar 8,3\%-9,9\%, India 10,1\%, bahkan di Guam mencapai $14 \% .{ }^{2}$ Pada penelitian yang dilakukan Felipe \& Siqueira ${ }^{3}$ dilaporkan bahwa satu dari 25 anak dalam populasi mengalami kejang demam setidaknya satu kali selama masa kanak-kanaknya.

Etiologi dari kejang demam hingga saat ini belum diketahui secara pasti, tampak ada beberapa faktor penting yang menyebabkan perkembangan kejang. Faktor risiko tersebut termasuk keterlambatan perkembangan, riwayat keluarga dengan kejang demam, dan defisiensi besi dan seng. ${ }^{4}$ Demam sering disebabkan infeksi saluran pernapasan akut, otitis media, pneumonia, gastroenteritis dan infeksi saluran kemih. ${ }^{5}$

Infeksi saluran pernapasan akut (ISPA) merupakan penyakit yang sering diderita oleh bayi dan anak. ${ }^{6}$ Klasifikasi ISPA menjadi ISPA bagian atas dan ISPA bagian bawah. ${ }^{7}$ Penelitian yang dilakukan Gourabi ${ }^{8}$ membuktikan dari 214 pasien anak yang mengalami kejang demam, $72,9 \%$ penyakit primernya adalah ISPA bagian atas, sedangkan ISPA bagian bawah adalah $1,4 \%$.

Hemoglobin adalah suatu kompleks protein yang terdiri atas gugus heme dan globin. Penurunan kadar hemoglobin di bawah nilai rentang normal disebut dengan anemia. ${ }^{9}$ Batasan anemia anak usia 6-59 bulan adalah kadar hemoglobin di bawah $11 \mathrm{~g} / \mathrm{dL} .{ }^{10} \mathrm{Kadar}$ hemoglobin di bawah batas normal menyebabkan kemampuan darah untuk mengangkut oksigen ke jaringan berkurang sehingga dapat menyebabkan hipoksia jaringan. Sementara oksigen diperlukan untuk proses metabolisme termasuk bagi perkembangan dan aktivitas otak. ${ }^{11,12}$

Anemia dapat disebabkan oleh beberapa faktor, seperti defisiensi besi, defisiensi asam folat (B9), defisiensi kobalamin (B12) dan defisiensi vitamin A. ${ }^{13}$ Sekitar lebih dari 50\% kasus anemia merupakan anemia defisiensi besi dan merupakan organ yang cukup sensitif terhadap besi. ${ }^{10,14}$ Vaswani ${ }^{15}$ melaporkan bahwa defisiensi besi berhubungan dengan kejang demam. Zat besi berperan dalam produksi serotonin, dopamin, dan gamma amino-butyric acid (GABA), serta mielinasi, dan metabolisme neurotransmitter. Ketidakseimbangan antara neurotransmitter eksitator asam glutamat dan inhibitor GABA berperan penting dalam menimbulkan kejang demam. ${ }^{2}$ Sistem saraf pusat terus berkembang semenjak intrauteri hingga tahuntahun pertama paska natal. Gangguan mielinisasi yang disebabkan kekurangan zat besi menyebabkan seorang anak yang demam rentan mengalami kejang demam. ${ }^{16}$ Defisiensi zat besi berarti penurunan level dari serum ferritin sehingga akan menurunkan nilai ambang kejang pada anak. ${ }^{17}$

Penelitian Kumari ${ }^{18}$ mendapatkan hasil yang sangat bermakna antara anemia defisiensi besi dan kejang demam sederhana. Penelitian serupa juga pernah dilakukan Dasmayanti ${ }^{19}$ di Rumah Sakit Umum Daerah dr. Zainoel Abidin Banda Aceh, yang mendapatkan adanya perbedaan pada distribusi kejadian penurunan kadar hemoglobin antara kelompok kasus (kejang demam) dengan kontrol (demam tanpa kejang).

Berdasarkan penjabaran diatas, maka tulisan ini dibuat untuk mengetahui hubungan kadar hemoglobin dengan kejang demam pada anak yang disebabkan ISPA di RSUD Abdul Wahab Sjahranie Samarinda.

\section{Metode}

Penelitian ini merupakan jenis penelitian observasional analitik dengan metode kasus-kontrol yang bertujuan untuk mengetahui hubungan kadar hemoglobin dengan kejang demam pada anak yang disebabkan ISPA di RSUD Abdul Wahab Sjahranie Samarinda. Variabel bebas adalah kadar hemoglobin, sedangkan variabel tergantung adalah kejang demam yang disebabkan ISPA. Cara pengambilan sampel dilakukan dengan menggunakan teknik purposive sampling, dengan kejang demam sebagai kasus dan kejang tanpa demam sebagai kontrol. Data diambil dari rekam medik di RSUD Abdul Wahab Sjahranie Samarinda periode 2016-2017 dengan cara mengisi lembat checklist yang dibuat peneliti. Kriteria inklusi adalah pasien kejang demam rawat inap berusia 6 bulan -5 tahun, penyebab kejang demam adalah ISPA, status gizi baik atau kurang sesuai umur. Kriteria eksklusi adalah terdapat riwayat kejang tanpa demam, infeksi intrakranial, gangguan tumbuh kembang, status gizi obesitas, kelainan 
neurologis sebelum dan sesudah kejang, dan terdapat penyakit penyerta lain selama perawatan. Uji t tidak berpasangan digunakan untuk melihat perbandingan kadar hemoglobin pada kelompok kasus dan kontrol, uji chi-square $\left(x^{2}\right)$ digunakan untuk menganalisis hubungan kadar hemoglobin dengan kejang demam yang disebabkan ISPA. Hasil bermakna signifikan bila $\mathrm{p}<0.05$. Semua data dianalisis menggunakan program perangkat lunak SPSS 23.0. Penelitian ini telah mendapatkan persetujuan dari Komite Etik Fakultas Kedokteran Universitas Mulawarman dengan nomor 039/KEPK-AWS/IV/2018.

\section{Hasil}

Enam puluh dua pasien anak terlibat dalam penelitian ini, terdiri dari 31 pasien kejang demam dan 31 pasien demam tanpa kejang. Karakteristik subyek penelitian tertera pada Tabel 1 . Tabel 1 menunjukkan jenis kelamin kasus kejang demam laki-laki $22(71 \%)$ dan perempuan $9(29 \%)$ pasien. Berdasarkan usia, pasien kejang demam terbanyak adalah usia $0-12$ bulan

12 pasien, diikuti 13-24 bulan, 25-36 bulan, 48-60 bulan, dan 37-48 bulan. Pada pasien kejang demam jumlah status gizi baik adalah $28(90,3 \%)$ dan gizi kurang $3(9,7 \%)$ pasien. Berdasarkan klasifikasi, kejang demam dibagi menjadi kejang demam sederhana 20 pasien dan kejang demam kompleks 11 pasien.

Tabel 2 menunjukkan rata-rata kadar hemoglobin pada kelompok kasus adalah 11,04 g/dL dan kelompok kontrol adalah 11,6 g/dL. Rentang kadar hemoglobin pada kelompok kasus adalah 9,20-12,5 g/dL dan kelompok kontrol adalah 9,50-13,5 g/dL. Hasil analisis menggunakan uji t tidak berpasangan didapatkan nilai $\mathrm{p}<0,05(\mathrm{p}=0,023)$. Hasil tersebut membuktikan bahwa terdapat perbedaan antara kadar hemoglobin pada kelompok kasus dengan kelompok kontrol.

Tabel 3 menunjukkan analisis bivariat menggunakan uji chi-square. Hasil uji statistik menunjukkan adanya hubungan yang signifikan antara kadar hemoglobin dengan kejang demam yang disebabkan ISPA, $p=0,032(p<0,05)$. Berdasarkan nilai OR, anak dengan kadar hemoglobin rendah memiliki risiko

Tabel 1. Karakteristik subyek penelitian

\begin{tabular}{lcc}
\hline \multirow{2}{*}{ Karakteristik } & Kejang demam & $\begin{array}{c}\text { Demam tanpa } \\
\text { kejang }\end{array}$ \\
\cline { 2 - 3 } & Frekuensi & Frekuensi \\
\hline Jenis kelamin (n=62) & & \\
Laki-laki & 22 & 15 \\
Perempuan & 9 & 16 \\
Usia (bulan) & & \\
$0-12$ & 12 & 6 \\
$13-24$ & 9 & 9 \\
$25-36$ & 7 & 7 \\
$37-48$ & 1 & 7 \\
$48-60$ & 2 & 2 \\
Status gizi & & \\
Kurang & 3 & 4 \\
Baik & 28 & 27 \\
\hline
\end{tabular}

Tabel 2. Kadar hemoglobin subyek penelitian

\begin{tabular}{lccccc}
\hline Kadar hemoglobin & Kejang demam & Demam tanpa kejang & p & OR & IK 95\% \\
\hline Normal & 16 & 25 & 0,032 & 3,906 & $1,255-12,163$ \\
Rendah & 15 & 6 & & & \\
\hline Total & 31 & 31 & & & \\
\hline
\end{tabular}

Tabel 3. Analisis hubungan kadar hemoglobin dengan kejang demam yang disebabkan ISPA

\begin{tabular}{lcc}
\hline Hemoglobin & Kasus & Kontrol \\
\cline { 2 - 3 } & $(\mathrm{g} / \mathrm{dL})$ & $(\mathrm{g} / \mathrm{dL})$ \\
\hline Rerata & 11,04 & 11,6 \\
Median & 11,3 & 11,8 \\
SD & 0,81 & 1,05 \\
Min-Max & $9,20-12,5$ & $9,50-13,5$ \\
\hline
\end{tabular}


3,906 kali lebih besar untuk mengalami kejang demam dibandingkan dengan kadar hemoglobin normal.

\section{Pembahasan}

Kejang demam merupakan manifestasi klinis akibat pelepasan muatan listrik yang berlebihan di sel neuron otak karna gangguan pada pengendalian listrik intraselular maupun ekstraselular ${ }^{20}$. Demam adalah faktor utama kejang demam. Sementara infeksi saluran pernapasan atas merupakan penyebab demam utama selain gastroenteritis dan demam berdarah dengue. ${ }^{21}$

Karakteristik pasien menurut jenis kelamin didominasi oleh laki-laki. Hal tersebut sejalan dengan penelitian yang dilakukan di Rumah Sakit Anak dan Bunda Harapan Kita pada tahun 2012 yang melaporkan bahwa jenis kelamin pasien kejang demam, baik yang mengalami rekurensi (kekambuhan) kejang demam maupun tidak mengalami rekurensi, sebagian besar adalah laki-laki $(25,6 \% \text { dan 26,9\%) })^{22}$

Karakteristik berdasarkan usia menunjukkan pasien kejang demam terbanyak adalah kelompok usia 0-12 bulan. Hal tersebut sejalan dengan penelitian yang dilakukan di Saudi Arabia pada tahun 2015 bahwa kejadian kejang demam terbanyak terjadi pada pasien kelompok usia kurang dari 12 bulan yaitu 58 $(43,9 \%)$ pasien. ${ }^{23}$

Karakteristik berdasarkan status gizi, pasien kejang demam terbanyak adalah gizi baik. Hal tersebut sesuai dengan penelitian yang dilakukan di RSUP Prof. Dr. R. D. Kandou pada tahun 2016 bahwa distribusi kasus kejang demam terbanyak adalah dengan status gizi normal $(67,3 \%){ }^{24}$

Berdasarkan klasifikasi, pasien kejang demam didominasi oleh kejang demam sederhana. Hal tersebut sejalan dengan penelitian yang dilakukan di Rumah Sakit Anak dan Bunda Harapan Kita pada tahun 2012 yang melaporkan kasus kejang demam sederhana sebanyak $32(37,2 \%)$ dan kasus kejang demam kompleks $9(10,4 \%){ }^{22}$

Kadar hemoglobin merupakan salah satu indikator untuk menentukan terjadinya anemia. Anemia defisiensi besi merupakan anemia yang terbanyak ditemukan di Indonesia. Prevalensi anemia defisiensi besi anak usia pra sekolah diperkirakan sebesar $55,5 \% .^{25}$

Terdapat perbedaan bermakna antara kadar hemoglobin pada pasien kejang demam dan demam tanpa kejang yang disebabkan ISPA. Hal tersebut sejalan dengan penelitian yang dilakukan Karimi $\mathrm{dkk}^{26}$ yang melaporkan terdapat hubungan antara anemia defisiensi besi dengan kejang demam di Asia. Penelitian ini juga sejalan dengan penelitian yang dilakukan di Iran pada tahun 2013 yang bertujuan untuk mengetahui faktor risiko anemia defisiensi besi terhadap kejang demam Penelitian tersebut terdiri dari 100 pasien yang merupakan kasus dan kontrol, nilai rata-rata kadar hemoglobin pasien yang mengalami kejang demam didapatkan $11,46 \mathrm{~g} / \mathrm{dL}$, sedangkan pada demam tanpa kejang didapatkan 11,9 g/dL. Terdapat perbedaan yang bermakna antara kadar hemoglobin pada kasus dan kontrol ${ }^{27}$.

Dasmayanti $\mathrm{dkk}^{19}$ melaporkan bahwa terdapat hubungan kadar hemoglobin dengan kejang demam pada anak usia balita di RSUD dr. Zainoel Abidin Banda Aceh pada tahun 2015. Penelitian Dasmayanti diakukan pada 25 subyek kejang demam dan 25 subyek demam tanpa kejang. Penelitian tersebut menggunakan metode cross sectional yang mengikutsertakan seluruh pasien kejang demam dengan penyakit primer apapun. Pada penelitian ini dilakukan pada 31 subyek kejang demam dan 31 subyek demam tanpa kejang dengan metode case control. Pemilihan ISPA sebagai penyakit primer kejang demam tanpa gastroenteritis dan demam berdarah dengue untuk menghindari salah tafsir dari kadar hemoglobin yang menurun akibat penyakit primer dan hemokonsentrasi.

Penelitian ini juga sejalan dengan penelitian case control yang dilakukan di Iran pada tahun 2016 yang melaporkan data bahwa $45 \%$ dari pasien kejang demam mengalami anemia defisiensi besi, sedangkan pada pasien demam tanpa kejang hanya $22 \%$ di antaranya yang mengalami anemia defisiensi besi. Hemoglobin sebagai salah satu parameter status hematologik secara bermakna lebih rendah pada kelompok kasus dibanding kelompok kontrol. ${ }^{28}$ Penelitian ini juga didukung oleh Sit $\mathrm{dkk}^{29}$ (2016) yang memperoleh data bahwa dari 50 pasien kejang demam memiliki kecenderungan 6.303 kali menderita anemia defisiensi besi dibanding pasien kontrol.

Berdasarkan teori, kekurangan kadar hemoglobin dalam darah menyebabkan kemampuan sel darah merah mengikat oksigen menurun, sementara oksigen diperlukan dalam proses metabolisme termasuk bagi perkembangan dan aktivitas sel otak. ${ }^{12}$ Sirkulasi otak pada anak berumur 3 tahun mencapai 65\% dari seluruh tubuh dibanding dengan orang dewasa 
Amalia Aswin dkk: Hubungan kadar hemoglobin dengan kejang demam yang disebabkan infeksi saluran pernapasan akut

yang hanya $15 \%$. Kenaikan suhu tubuh pada level tertentu mengakibatkan perubahan permeabilitas dari membran sel neuron dan depolarisasi membran dalam waktu yang singkat. ${ }^{20}$ Apabila anemia ini disebabkan defisiensi besi maka kandungan besi dalam otak akan berkurang. ${ }^{12}$ Defisiensi besi menstimulasi fungsi neuron dan meningkatkan risiko kejang demam. ${ }^{30}$ Anemia defisiensi besi dapat menginduksi terjadinya kejang melalui mekanisme hipoksemia, perubahan pada saraf serta metabolisme otak, dan gangguan mielinisasi. Besi berhubungan dengan aktivitas enzim aldehid dan monoamin oksidase, suatu enzim yang sangat penting untuk laju degradasi normal dari neurotransmitter. ${ }^{28}$ Perubahan pada neurotransmitter, seperti norepinephrine, dopamin, serotonin, dan terutama gamma-aminobutyric acid (GABA) serta asam glutamat dapat menimbulkan bangkitan kejang demam. ${ }^{30}$ Defisiensi besi juga menyebabkan gangguan pada mielinisasi serta pembentukan tirosin dan triptofan hidroksilase, tirosin dan triptofan hidroksilase berperan penting dalam pembentukan neurotransmitter dan pelepasan neurotransmitter dari vesikel. ${ }^{31}$

\section{Kesimpulan}

Berdasarkan hasil penelitian dan pembahasan yang telah diuraikan maka dapat ditarik kesimpulan bahwa terdapat hubungan kadar hemoglobin dengan kejang demam pada anak yang disebabkan ISPA. Hasil analisis menunjukkan bahwa anak dengan kadar hemoglobin rendah berisiko 3,906 kali mengalami kejang demam.

\section{Daftar pustaka}

1. Ikatan Dokter Anak Indonesia. Rekomendasi penatalaksanaan kejang demam. Jakarta: Badan Penerbit IDAI; 2016.h.1.

2. Khanis A. Defisiensi besi dengan parameter sTfR sebagai faktor risiko bangkitan kejang demam (Tesis). Semarang: Departemen Ilmu Kesehatan Anak Universitas Diponegoro, 2010.

3. Felipe L, Squeira M. Febrile seizures: update on diagnosis and management. Italian J Pediatr 2010;56:489-92.

4. Graves R, Oehler K, Tingle L. Febrile seizures: risks, evaluation, and prognosis. Jan 2012 (Diunduh pada 2 Februari 2018). Didapat dari: URL:https://www.aafp.orglafp/2012/0115/p149.pdf.

5. Soetomenggolo T. Kejang demam. Dalam: Soetomenggolo T, Ismael S, penyunting. Buku ajar neurologi anak. Edisi kedua. Jakarta: IDAI; 2000.h.245.
6. Kementerian Kesehatan RI. Pedoman pengendalian infeksi saluran pernapasan akut. Jakarta: Kementrian Kesehatan RI; 2011.

7. Simoes E, Cherian T, Chow J, Shahid-Salles S, Laxminarayan $\mathrm{R}$, John T. Acute respiratory infection in children. Disease Control Priorities in Developing Countries 2006;2:483.

8. Gourabi H. Febrile seizure: demographic features and causative factors. Iranian J Child Neurol 2012;6:33-7.

9. Lichtman M, Kaushansky K, Prchal J, Levi M, Burns L, Armintage J. Williams manuals of hematology. Edisi kesembilan. China: McGraw-Hill Education; 2013.

10. WHO. Haemoglobin concentrations for the diagnosis of anaemia and assessment of severity. WHO. 2001 (Diunduh pada 10 Februari 2018). Didapat dari: URL: http://www.who. int/vmnis/indicators/haemoglobin.pdf.

11. Hamid A. Clinical Hematology. Edisi pertama. Yemen: University of Aden; 2013.

12. Hidayati L, Hadi H, Lestariana W, Kumara A. Anemia dan prestasi belajar anak sekolah dasar. Jurnal Kesehatan Universitas Muhammadiyah Surakarta 2010;3:107.

13. Arsenault J, Mora-Plazas M, Forero Y, Lopez-Arana S, Baylin A, Villamor E. Hemoglobin concentration is inversely associated with erythrocyte folate concentrations in Colombian school-age children, especially among children with low vitamin B12 status. Eur J Clin Nutr 2009;63:842-43.

14. Hartfield DS, Tan J, Yager J, dkk. The association between iron deficiency and febrile seizures in childhood. Clin Pediatr 2009;48:420-26.

15. Vasmani R. Iron deficiency as a risk factor for first febrile seizure. Indian Pediatrics 2010;47:437.

16. Siddiqui T. Febrile convulsion in children: relationship of family history to type of convulsions and age at presentation. J Ayub Med Coll 2002;14:4.

17. Ahmed B. Iron Deficiency as a risk factor for simple febrile seizures. Med J Cairo Univ 2013;81:53.

18. Kumari P, Nair M, Nair S, Kailas L, Geetha S. Iron deficiency as a risk factor for simple febrile seizures-a case control study. Indian Pediatrics 2011;49:17-9.

19. Dasmayanti Y, Anidar, Imran, Bakhtiar, Rinanda T. Hubungan kadar hemoglobin dengan kejang demam pada anak usia balita. Sari pediatri 2015;16;354.

20. Satyanegara. Ilmu bedah saraf. Edisi kelima.Jakarta: Gramedia Pustaka Utama; 2014.h.273.

21. Geminita, T. Gambaran Pasien Kejang Demam Rawat Inap di RSUD Abdul Wahab Sjahranie Samarinda Periode Januari 2014 - Desember 2015 (skripsi). Samarinda: Universitas Mulawarman, 2015.

22. Dewanti A, Widjaja J, Tjandrajani A, Burhany A. Kejang demam dan faktor yang mempengaruhi rekurensi. Sari Pediatri 
Amalia Aswin dkk: Hubungan kadar hemoglobin dengan kejang demam yang disebabkan infeksi saluran pernapasan akut

2012;14:57.

23. Jamal M, Ahmed W. To identify the factors affecting the risk of recurrent febrile seizures in Saudi Children. Pak Armed Forces Med J 2015;65:458.

24. Kakalang JP, Masloman N, Manoppo J. Profil kejang demam di Bagian Ilmu Kesehatan Anak RSUP Prof. Dr. R. D. Kandou Manado periode Januari 2014 - Juni 2016. Jurnal e-Clinic 2016;4:2.

25. Ratnadi IGA, Soetjiningsih S. Iron status in breast-fed infants. PI (serial online). Aug 2001. Diunduh pada 28 Juni 2018. Didapat dari :URL:https://paediatricaindonesiana.org/index. php/paediatrica-indonesianalarticle/view/1073.

26. Karimi P, Badfar G, Soleyman A, Khorshidi A, Tardeh Z. Association of iron deficiency anemia and febrile seizure in Asia: A systematic review and meta-analysis. Iranian J Neonatol 2018;9:43.
27. Fallah R, Tirandazi B, Karbasi S, Golestan M. Iron deficiency and iron deficiency anemia in children with febrile seizure. Iranian J Pediatr Hematol 2013;3:112.

28. Meena J, Meena S, Sitaraman S. The correlation of iron status and first febrile seizure: a prospective case-control study. IOSR J Dent Med Sci 2016;15:42.

29. Sit S, Maiti S, Kant M, Mandal S, Mandal A. Iron deficiency anemia: a probable risk factor for first episode of simple febrile seizure. IOSR Journal of Dental and Medical Sciences 2016;15:12.

30. Johnston MV. Iron deficiency, febrile seizures and brain development. Indian Pediatrics 2012;49:13-4.

31. Habibian N, Alipour A, Rezaianzadeh A. Association between Iron Deficiency Anemia and Febrile Convulsion in 3 to 60 month-old Children: A Systematic Review and Meta-Analysis. Iran J Med Sci 2014;39:496-505. 